ارزيابى ريسك آلودگى آرسنيك در دشت همدان - بهار با استفاده از روش فازى

مينا توزندهجانى"، عليرضا سفيانيان و نوراله ميرغفارى'

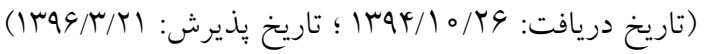

جكيده

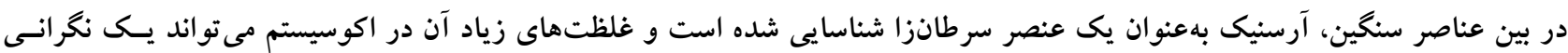

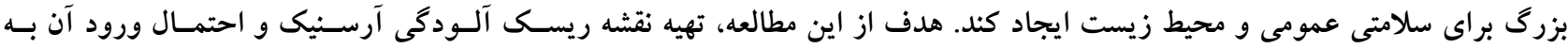

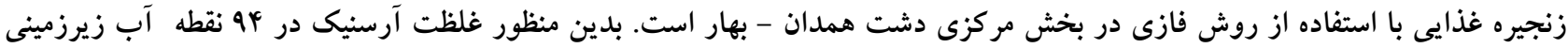

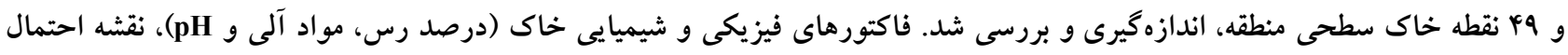

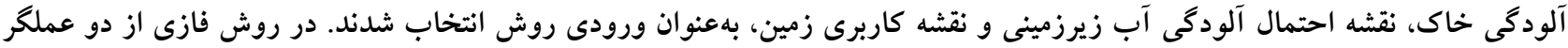

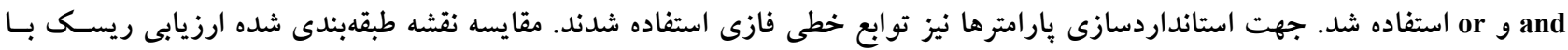

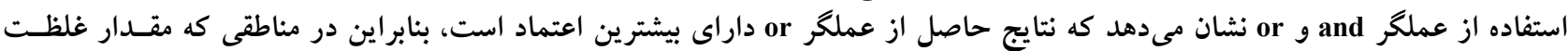

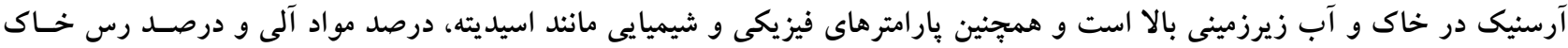

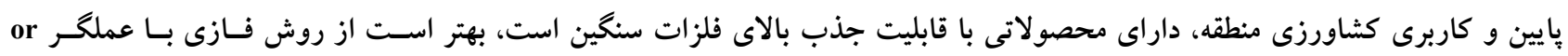

وازههاى كليدى: آرسنيك، دشت همدان - بهار، ريسك، روش فازى 
خراسان، كردستان، آذربايجان شرقى و غربى گزارش شده است،

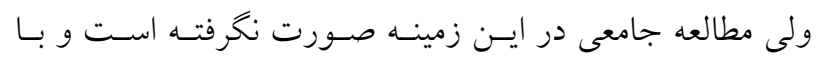

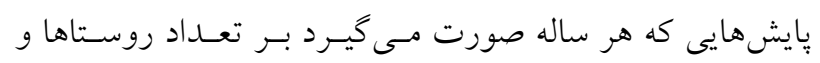

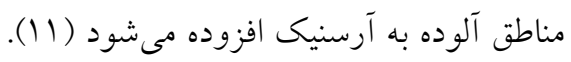

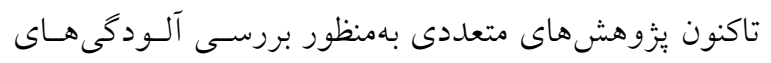

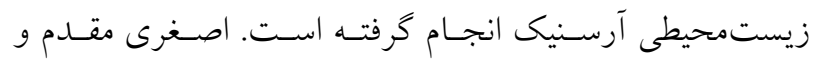

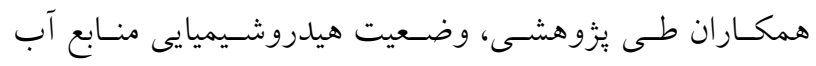

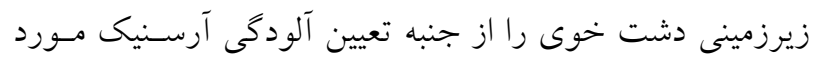

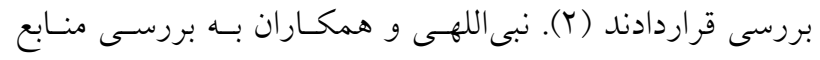

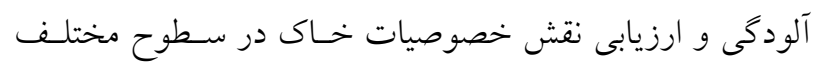

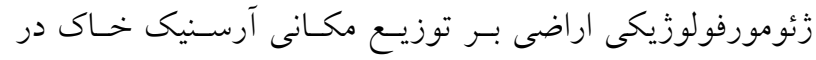

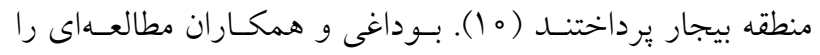

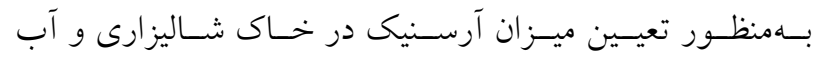

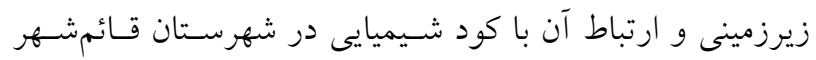

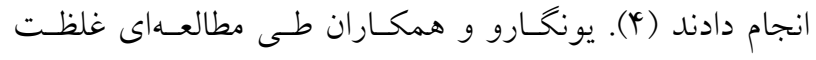

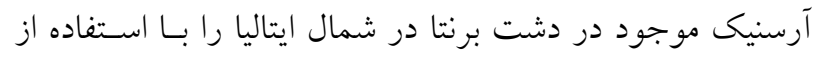

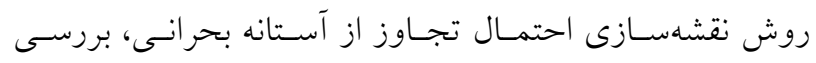

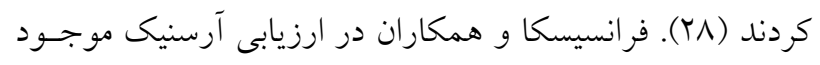

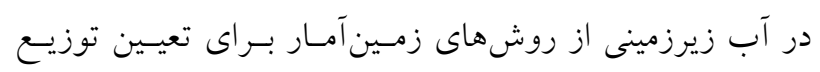

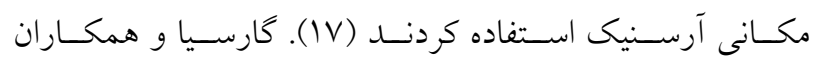

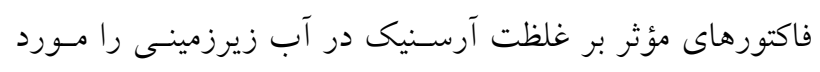
بررسى قرار دادند (1) (1).

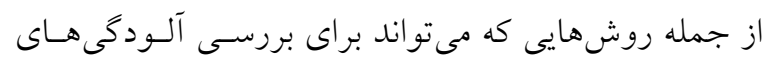

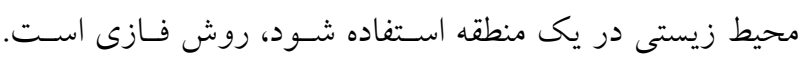

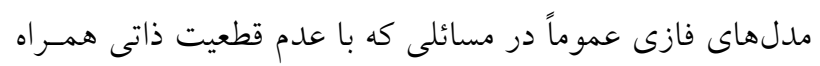

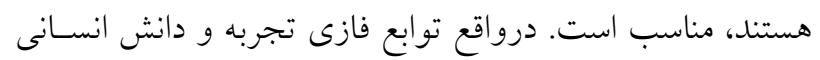

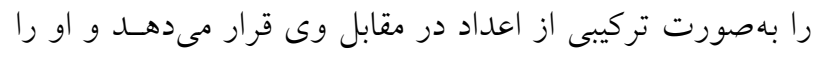

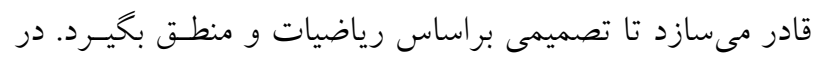

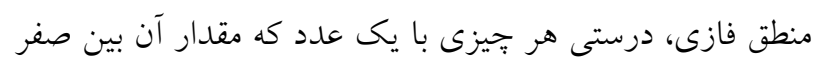

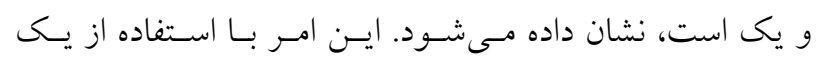

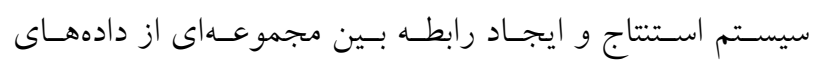

ورودى و مجموعهاى از دادههاى خروجى تحقق مى يابد (ه).

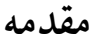

آلودگى زيستمحيطى شامل تغييرات نـامطلوب در مشخصـات

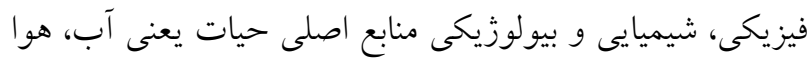

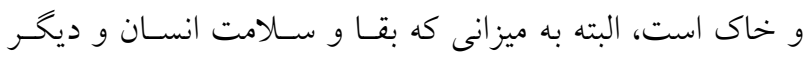

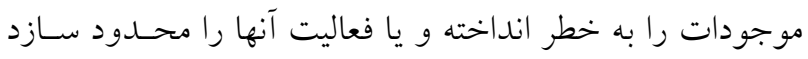
(YY)

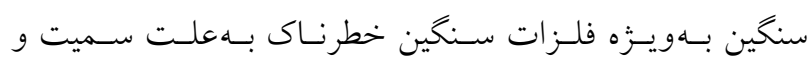

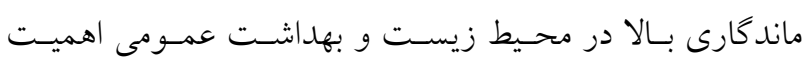

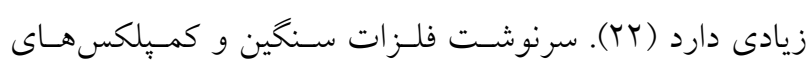

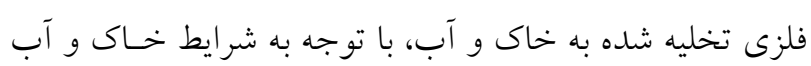

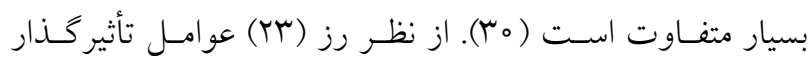

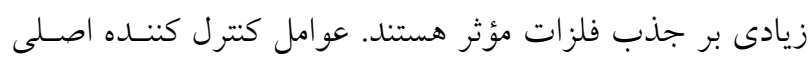

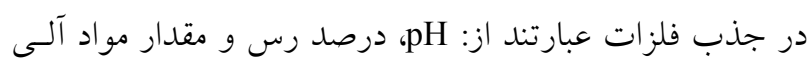

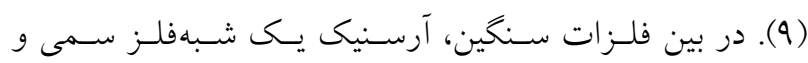

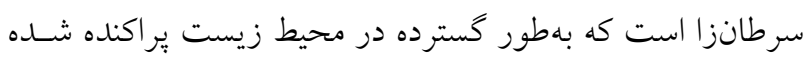

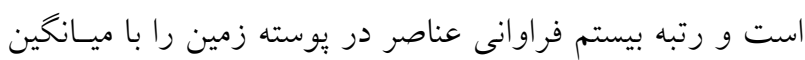

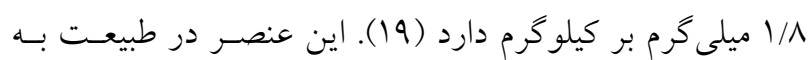

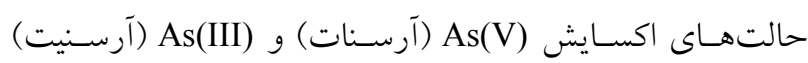

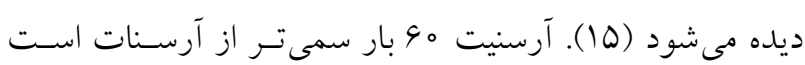

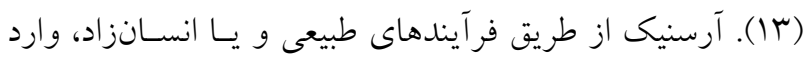

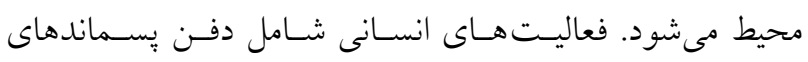

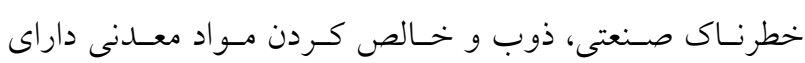

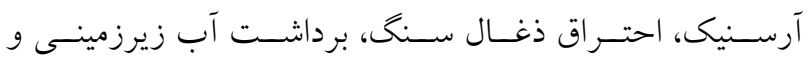

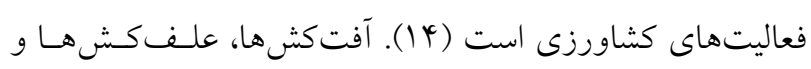

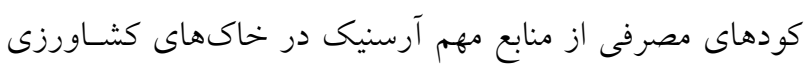

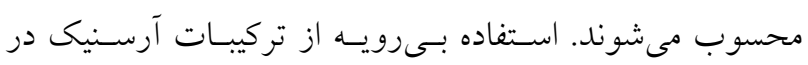

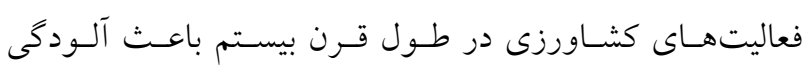

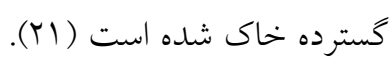

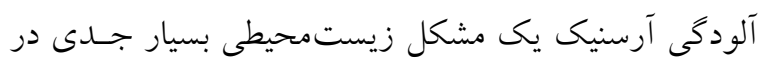

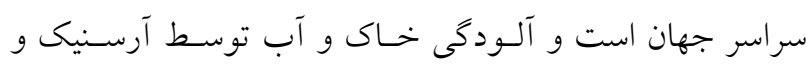

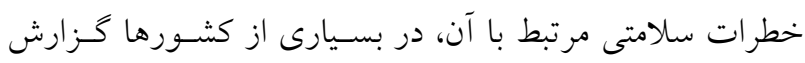

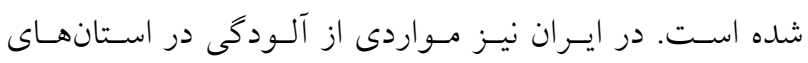


مجموعه تعلق مى گيرد. در روش استانداردسازى فازى، براى باز

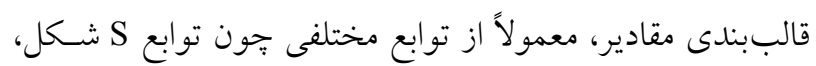
J شكل و خطى استفاده مىشود (N).

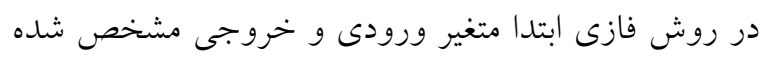

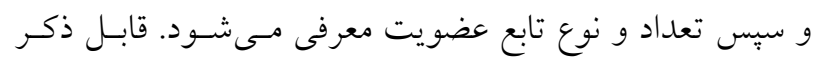

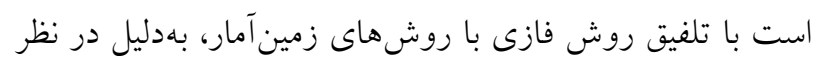

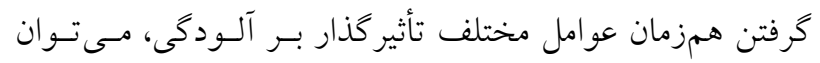

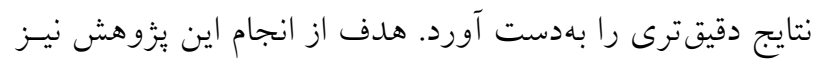

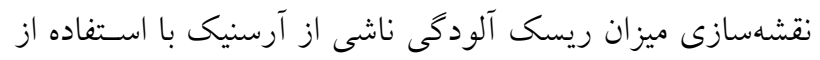

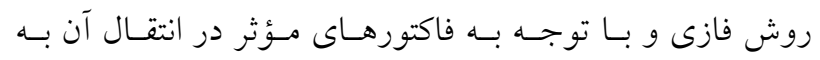
زنجيره غذايى در محدوده بخش مركزى دشـت همـــان -بهـار

مواد و روشها

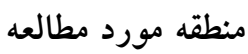
منطقه مورد مطالعه بخش مركزى دشت همدان - بهار است كـه مورد مهنه

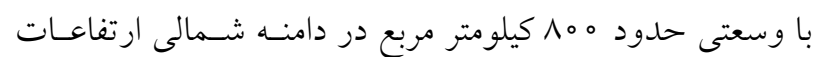

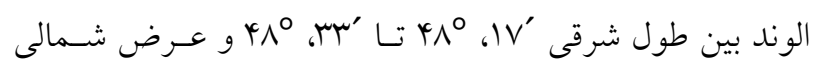
快 بخش هاى مركزى از شهرستان همدان و بخش هـاى لالـهـهين،

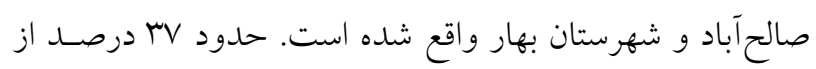

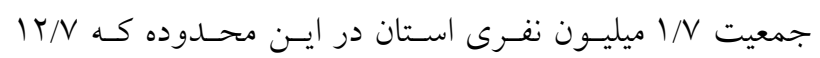

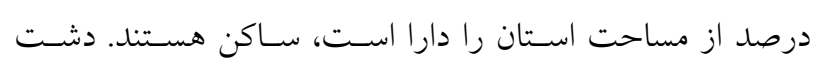

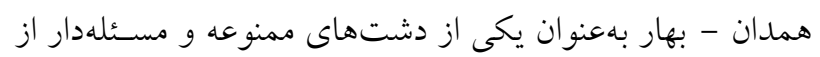

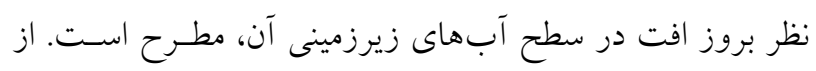

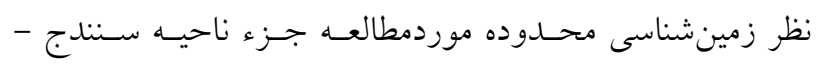

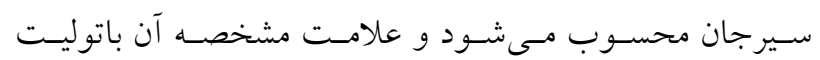
كرانيتى الوند است كه هسته ارتفاعات جنوبى حسوزه مـ را تشـكيل

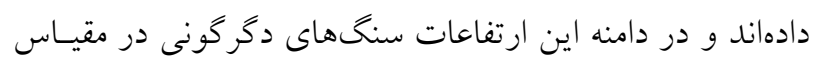

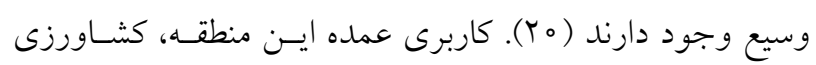

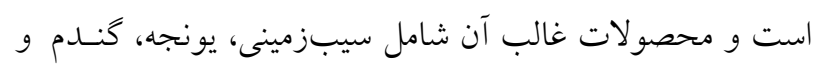

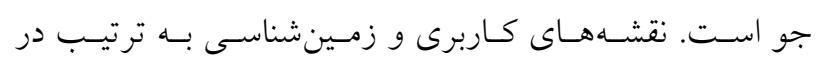

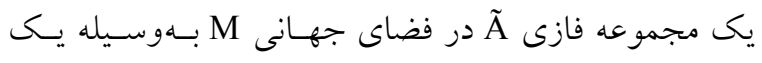
تابع

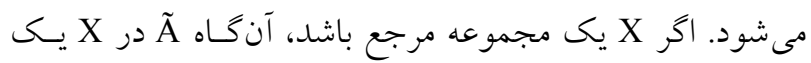

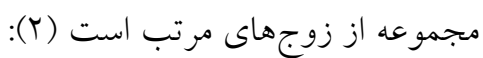
$\tilde{\mathrm{A}}=\left\{\left(\mathrm{x}, \mu \tilde{\mathrm{A}}^{\prime}(\mathrm{x})\right) \mid \mathrm{x} \in \mathrm{X}\right\}$

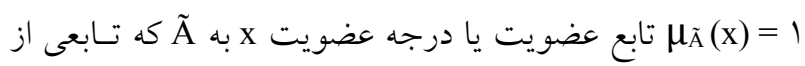

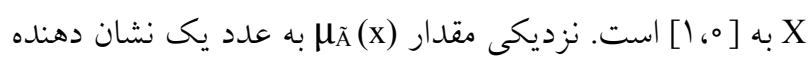

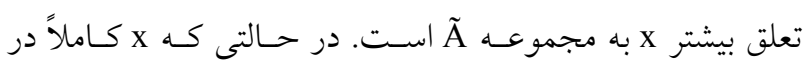

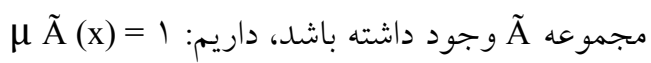

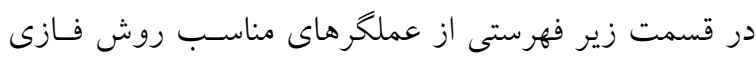

براى استفاده در برخى شرايط خاص آمده است (ه):

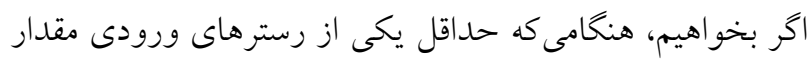

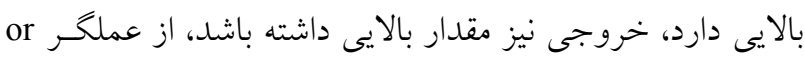
استفاده مىشود.

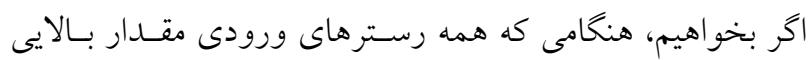

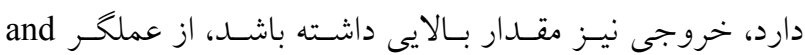

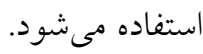
زمانى كه ميزان اهميت تركيب دادهها، از تكىتـى دادههــا كمتـر است از عملكر PRODUCT استفاده مىشود.

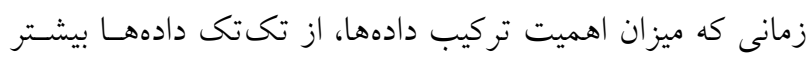
است از عملكر مRODUCT استفاده مىشود. در روش فازى براى همسانسازى مقياس هاى اندازهكيرى و

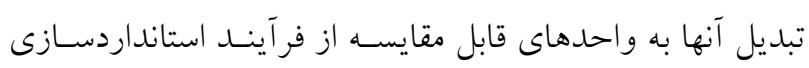

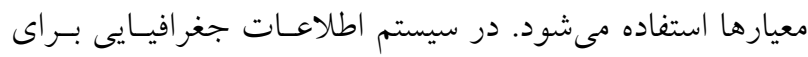

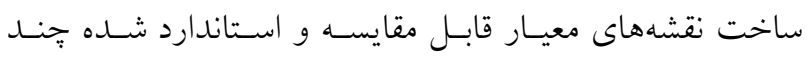
رويكرد اصلى شامل روشهاى قطعى، احتمالاتى و فازى وجود

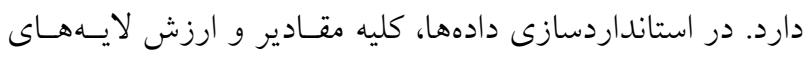

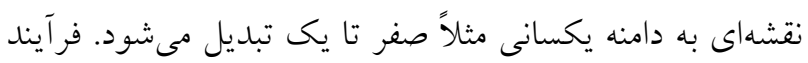

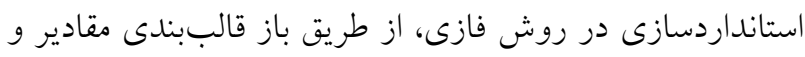
ارزشها، به شكل يك مجموعه عضسويت، عملسى مسى شــود. در

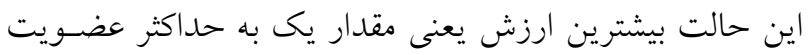
و كمتـرين ارزش يعنسى عــد صـفر بـهـ حسـاقل عضـويت در 


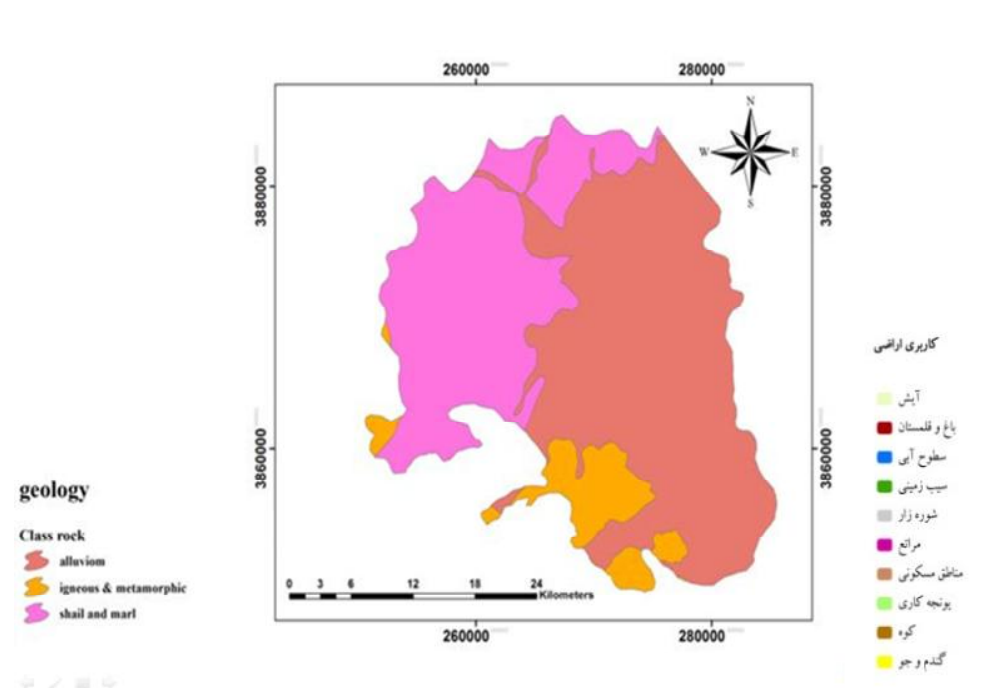

شكل Y. نقشه زمينشناسى منطقه

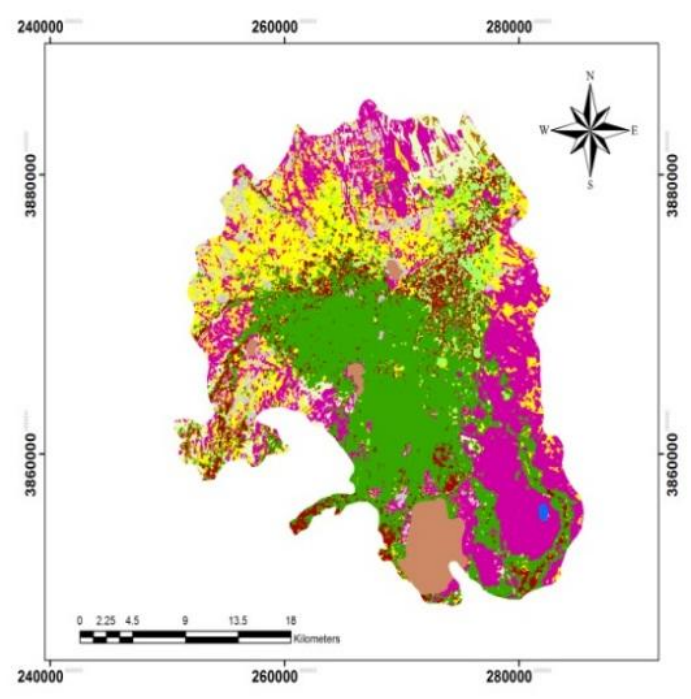

شكل ا. نقشه كاربرى اراضى منطقه

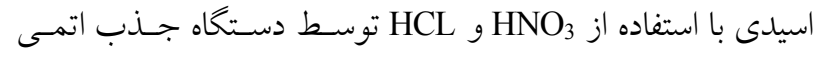
مورد آناليز قرار كرفتند (Y9). علاوه بــر ايسن برخـى از پارامترهـاى فيزيكى و شيميايى خاك شامل pH درصد رس و مواد آلى كـه در انتقال و جذب آلاينده توسط كياه مؤثرند، نيز اندازهيـرى شـد. pH نمونهها در كل اشباع خاك با استفاده از pH متر، درصـد مـاده آلى لى به روش تيتراسيون با استفاده از فروسولفات آمونيـوم، دى كرومـات

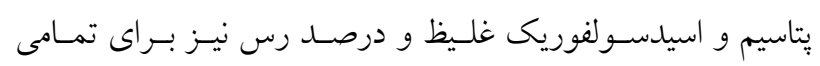
نمونها به روش هيدرومترى اندازهيرى شد شد (r).

\section{تجزيه و تحليلهاى آمارى}

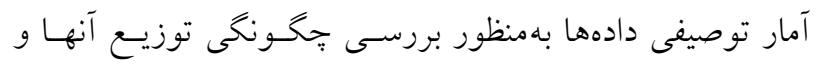
دستيابى به خلاصـهاى از اطلاعـات آمـارى دادههـاى مـوردنظر

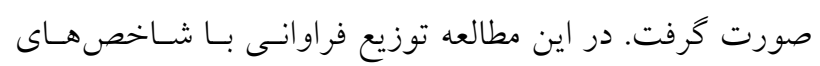

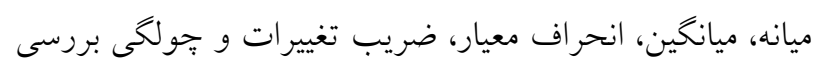

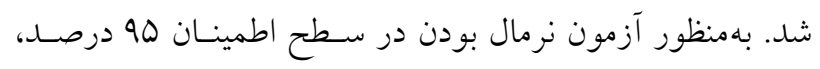
آماره كولموكروف - اسميرنوف استفاده شد. جهت نرمال كردن دادهها نيز از روش تبديل للخاريتم استفاده گرديد.

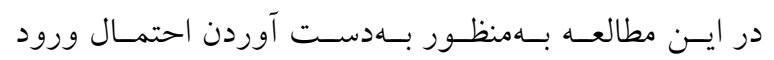

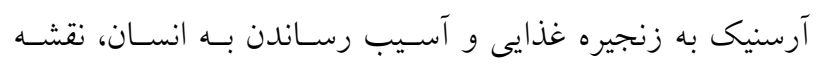

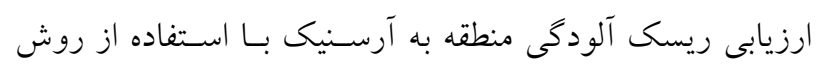

شكلهاى ( ا و r ب) نشان داده شده است از مطالعات مشـابهى كـه در منطقه مورد مطالعه، انجام گرفته بود، مورد استفاده قرار كرفت

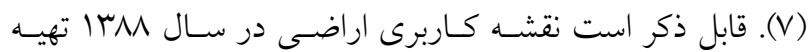
گرديده است. در شكل (r) بر اكنش نقاط نمونهــردارى در سـطح

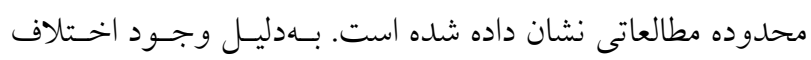
زمانى با نمونهبردارىها، صحت نقشه مذكور با استفاده از تصاوير ماهوارهاى و انجام عمليات ميدانى مورد بررسى قرار گرفت.

\section{روش تحقيق}

بهمنظور انجام ايسن تحقيـق، تعـداد وq نمونسه آب زيرزمينسى و 94 نمونه خاك سطحى منطقه مورد ارزيابى قرار گرفت. نمونسهبـــدارى خاك، براساس روش سيستماتيك تصـادفى انجـام گرفـت و بـــين منظور ابتدا منطقه مورد مطالعه با استفاده از نرمافزار GIS و تصـاوير

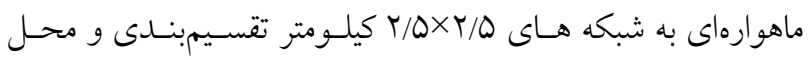
تاقى شبكهها بهعنوان نقاط نمونهبردارى درنظر گرفته شــ، سـبس در كار ميدانى، نقاطى كه در مناطق غير قابل دسترس نظير قلـههـا و

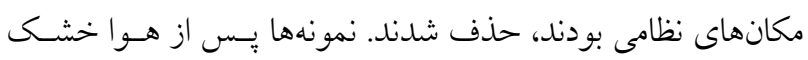
شدن، از الك دو ميلىمتر عبور داده و براى آناليز آماده شدند. بــراى

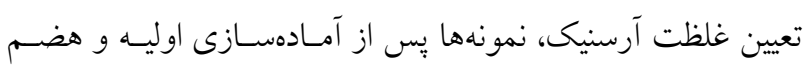




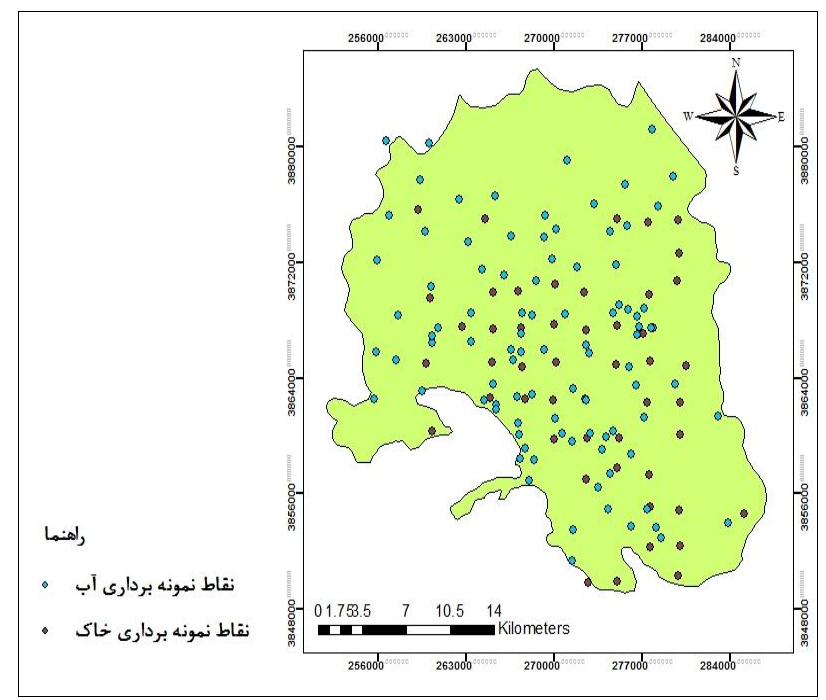

شكل r. براكنش نقاط نمونهبردارى

فلزات سنكين در خاى كاهش مسىيابــ و همجنــين بـالا بـودن درصد مواد آلى و درصـد رس خـاك، موجـب افـزايش جـــب فلزات سنخين توسط مواد آلى و ذرات رس خاى مسىشـود، در نتيجه با افزايش اين سه يارامتر، قابليت جذب فلزات سنخين در

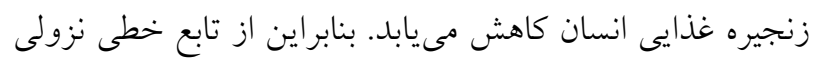

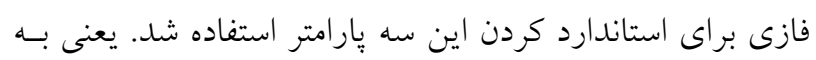
بالاترين مقدار در هر سه يارامتر (pH) درصد مواد آلى و درصد رس) مقدار تابع عضويت صـفر و بـهـ يـايين تـرين ارزش، تـابع عضويت يك داده مىشود.

نقشههاى احتمـال آلـودگى خـاك و آب زيرزمينسى نيـز بـا لـا اسـتفاده از روش كريجينـع شـاخص و بــا توجــه بـهـ حسـدود

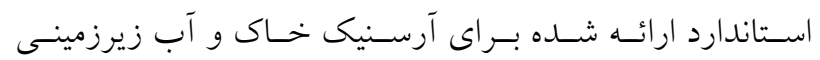

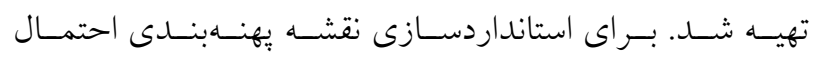
آلودكى آب زيرزمينسى و خـاك از تـابع خطى صـعودى فـازى استفاده شد، به اين معنى كه مقدار تابع عضويت يكى به منـاطقى ابـ كه داراى بالاترين درصد احتمال هستند، داده شد و مقدار تـابع عضويت صفر به مناطقى با كمترين درصــ احتمـال اختصـاص يافت.

يس از استانداردسازى يارامترها، بــراى تهيـهـ نقشـهـ ارزيـابى ريسك به روش فازى از عملكر and و or استفاده شد.
فازى و با توجه به فاكتورهاى مؤثر، تهيه شد. فاكتورهايى كه در اين مطالعـه درنظـر كرفتـه شـد، عبارتنـد از: نقشـهـ فاكتورهـاى فيزيكى شيميايى خاى (درصد رس، ماده آلى و pH) (شكل \&))، نقشه احتمال آلودگى آب (شكل ه)، نقشه احتمال آلودگى خاى (شكل 9) و نقشه كاربرى اراضى (شكل (1).

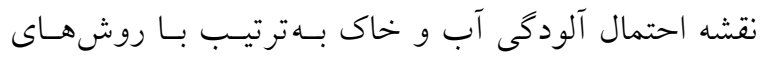

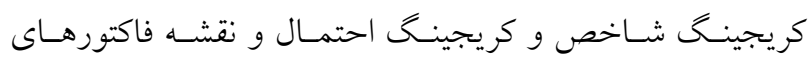
فيزيكى شيميايى خاك نيز با روش توابـع بايسه شـعاعى (RBF)

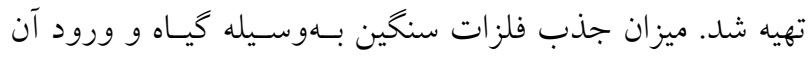
به زنجيره غذايى بستخى به قابليت جذب ايسن عنصـر در خـاى دارد. قابليت جذب فلزات سنخين در خاى نيز بـه غلظـت كـل فلزات سنخين و همين طور ويزّكى هاى خـاك ماننــ pH، ميـزان ماده آلى و درصد رس بستخى دارد.

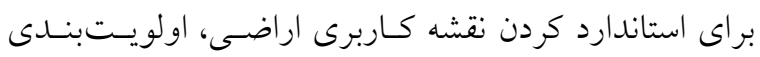
كاربرىها براساس ميزان مصرف محصولات غذايى و كوتاهترين مسير ورود آرسنيك به زنجيره غذايى انسان است. تابع عضويت فازى كاربرىها، با توجه به نظرات كارشناسان بهصورت جدول در نقشه يارامترهاى فيزيكى و شيميايى خاى (pH) مواد آلى و درصد رس) ازآنجايى كه با افزايش pH خاك، قابليـت حلاليـت 
نشريه علوم آب و خاك (علوم و فنون كشاورزى و منابع طبيعى) / سال بيست و دو / شماره دو / تابستان IrqV

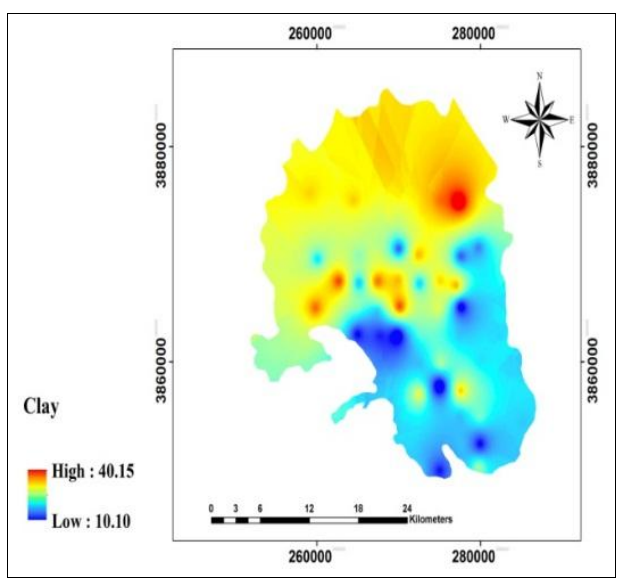

(ب)
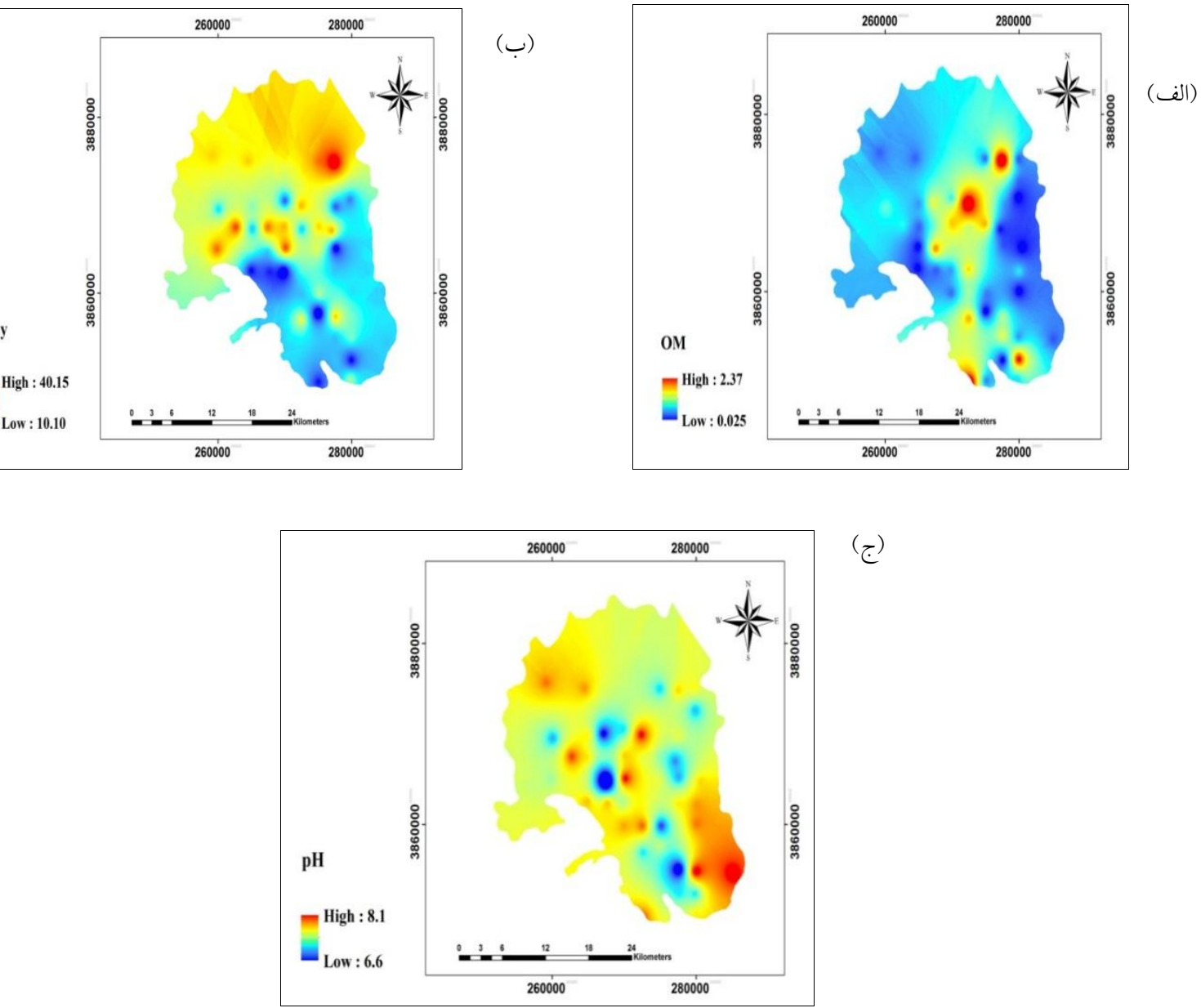

(ج)

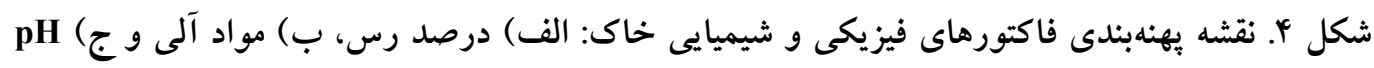

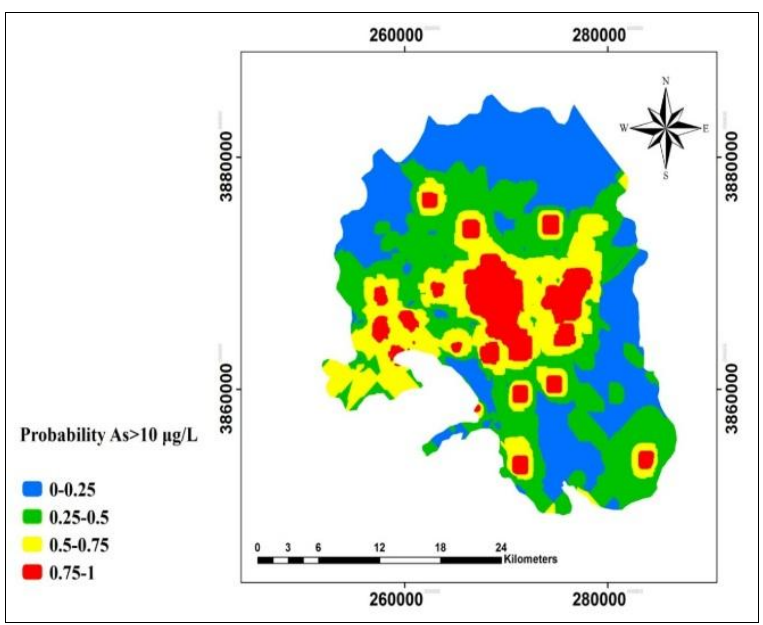

شكل ه. نقشه احتمال آلودگى آب و افزايش غلظت آرسنيك از حد آستانه ها ميكروگرم بر ليتر 


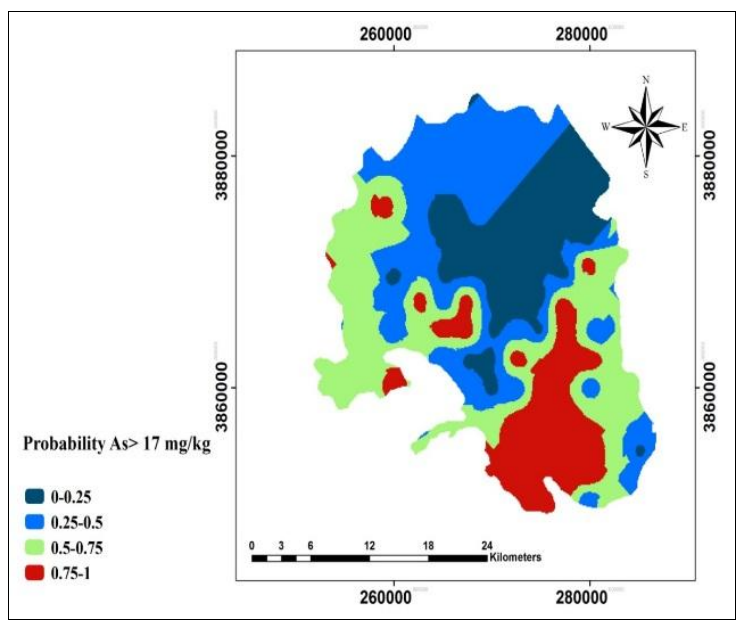

شكل و. نقشه احتمال آلودگى خاك و افزايش غلظت آرسنيك از حد آستانه V ميلى گرم بر كيلو گرم

\begin{tabular}{|c|c|}
\hline تابع عضويت فازى & نوع كاربرى \\
\hline 1 & كندم \\
\hline$\circ / 9$ & سيبزمينى \\
\hline$\circ / \Lambda$ & باغ \\
\hline$\circ / V$ & يونجه \\
\hline $0 / 9$ & مراتع \\
\hline$\circ / 0$ & سطوح آبى \\
\hline $0 / 4$ & شهر \\
\hline$\circ \mu$ & آيش \\
\hline $0 / r$ & كوه \\
\hline$\circ / 1$ & 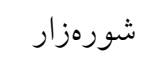 \\
\hline
\end{tabular}

بار امترهاى خاك، ماده آلى با N N/90 بيشترين ضريب تغييرات را نتايج و بحث

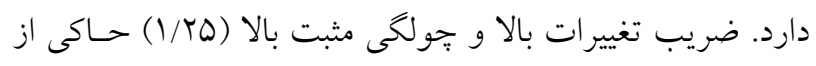

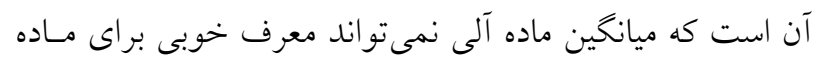

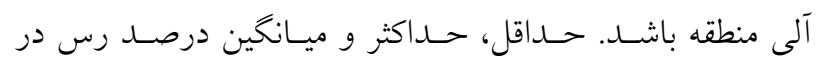

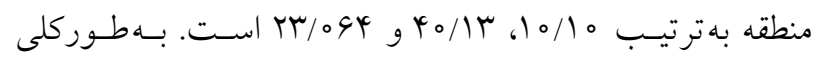
بافت خاك منطقه بيشتر لومى و لومى رسى است.

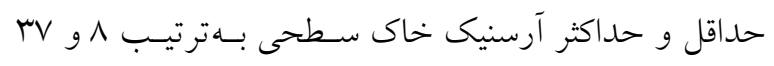

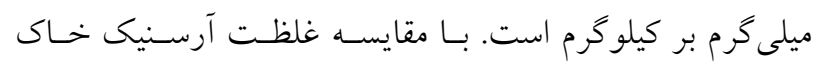

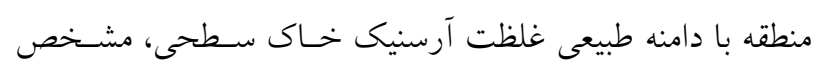

توصيف آمارى غلظت آرسـنيك در نمونسههـاى آب و خهـاك و

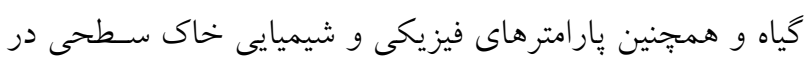
جدول r نشان داده شده است.

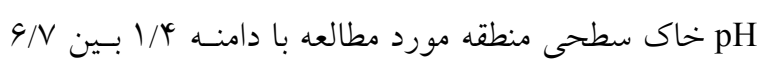

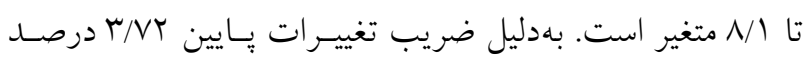

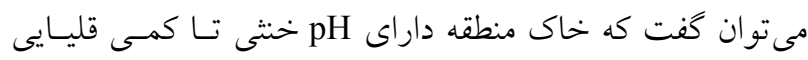

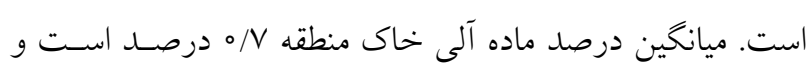

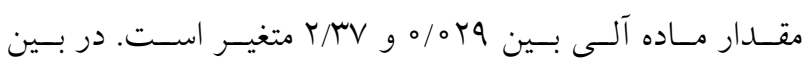


جدول r. توصيف آمارى دادهها

\begin{tabular}{|c|c|c|c|c|c|c|c|c|c|}
\hline جولى جى & دامنه & ضريب تغييرات & انحر اف معيار & 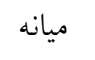 & ميانگين & حداكثر & حداقل & واحد & فاكتور \\
\hline$\circ / \Lambda Y$ & rq & $r V / F V$ & G/AV & $19 / 0$ & $|N / T|$ & rv & $\Lambda / \circ \circ$ & $\mathrm{mg} / \mathrm{kg}$ & آرسنيك خاك \\
\hline$r / 11$ & $v^{4}$ & $1 T Q / \Delta \circ$ & $10 / 09$ & v & $\mid r / 4$ & $V q / D$ & 0 & $\mu \mathrm{g} / 1$ & آرسنيك آب \\
\hline $1 / T \Delta$ & $r / \mu Y$ & $14 / 90$ & $\circ / 09$ & $\circ / 0 \circ$ & $\circ / \mathrm{V}$ & $r / M V$ & O/Or & $\%$ & ماده آلى خاى \\
\hline$-0 / 99$ & $1 / 4 \wedge$ & T/NT & $0 / T \wedge$ & $V / V D$ & $V / 9 \Lambda$ & $\Lambda / \Lambda$ & G/V & - & خاى pH \\
\hline$\circ / T V$ & $r_{0 / 0 r}$ & $\mu_{\circ} / r_{0}$ & $9 / 99$ & $T Y / \circ D$ & $r r / 0 \varphi$ & $r \circ / 1 r$ & $10 / 10$ & $\%$ & مقدار رس خاى \\
\hline
\end{tabular}

مركزى محدوده مطالعه و همجزنين در قسمت غـرب شهرسـتان

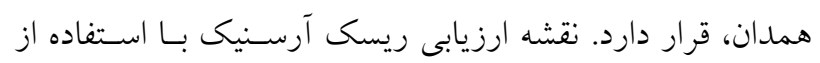

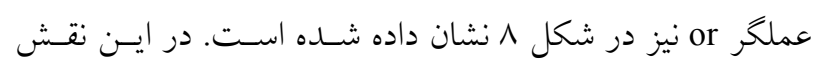

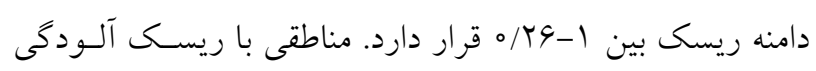

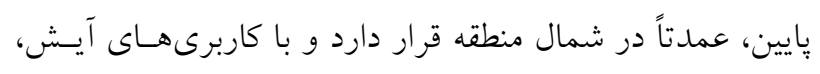
شورهزار و مراتع شـمال دشـت همخــوانى دارد، همجنـين روى هم گذارى اين نقشه با نقشههاى توزيع مكانى آرسنيك در خاك

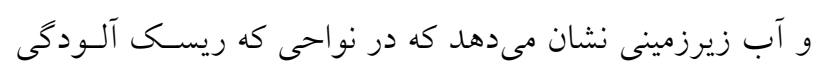
كمتر است، ميزان غلظت آرسنيك در خاك و آب زيرزمينى نيـز

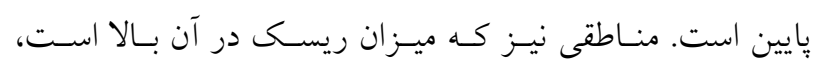

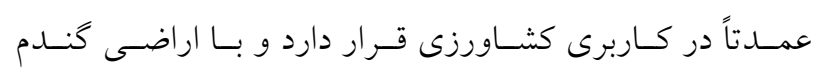
همخوانى دارد.

براى سهولت تفسير نقشههاى ارزيـابى ريسـى آلـودگى بـا

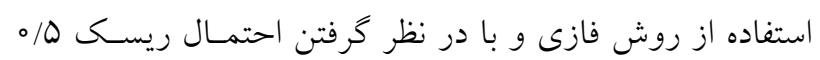

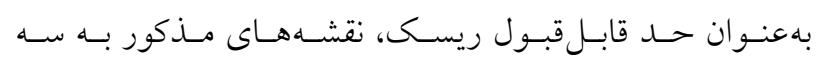

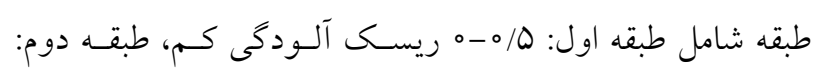

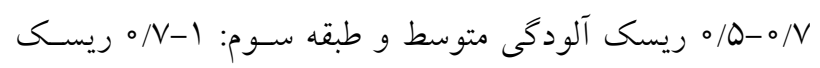
آلودخى زياد تقسيم شدند: الف) نقشه طبقهبندى شده ارزيابى ريسك آلودگى با استفاده از روش فازى عملكر and در شـكل 9 نشـان داده شــده اسـت. همجينين مساحت هر يـك از طبتـات و درصـد فراوانسى آن در جدول ب آمله است. همان كونه كه در شكل 9 مشاهده مى شــود، در نقشه ريسـك آلـودگى حاصـل از عملحـر and بـيش از 99 درصد منطقه مورد مطالعه در دامنه قابل قبول با ريسك آلـودگى دئى

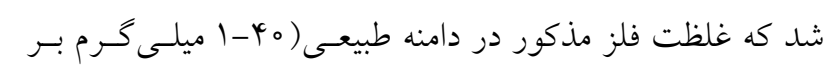

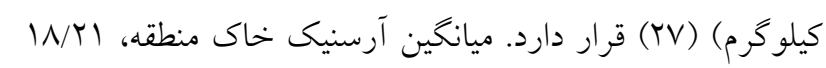

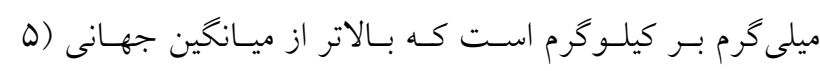
ميلى گرم بر كيلو گرم) (TV) و ميانخين كشورهايى مانند آمريكاو و

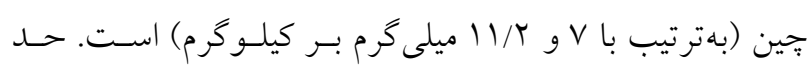

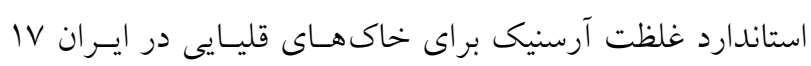
ميلى گرم بر كيلو گرم است (از جنبه حفاظت محيط زيستـ) (1) كه اين نشان مىدهد ميانخين آرسنيك منطقـه از حــــ اسـتاندارد تعيين شده براى خاكهاى ايران نيز تجاوز كرده است.

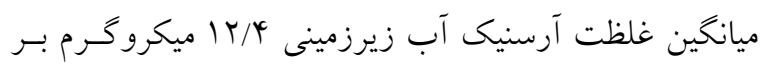

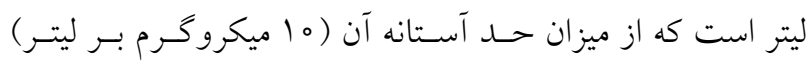

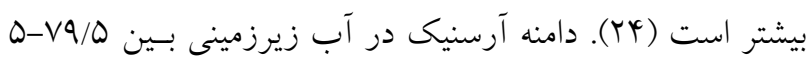
ميكرو گرم بر ليتر و ضريب تغييرات آن نيز بالا است.

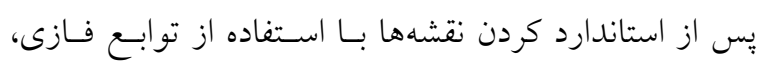
براى تهيه نقشه ارزيابى ريسك، عملحــ and و or بـهــار بـرده شد. عملكر and براى تهيه نقشههايى با حداقل اعتمـاد استفاده

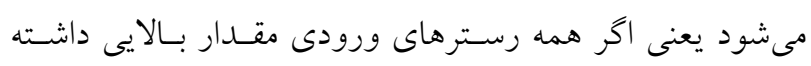
باشد، خروجى نيـز مقـدار بـالايى دارد. عملحـر or بـراى تهيـهـ

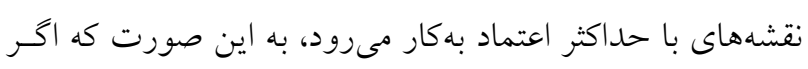

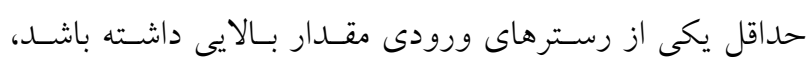
خروجى نيز مقدار بالايى دارد.

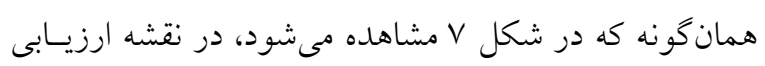

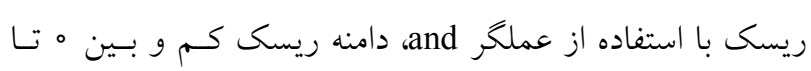

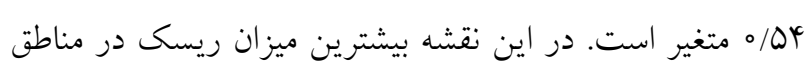




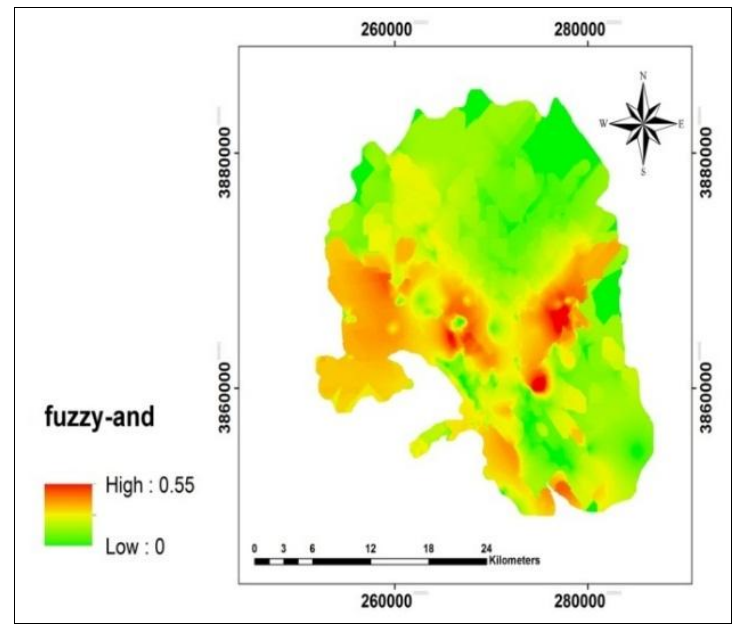

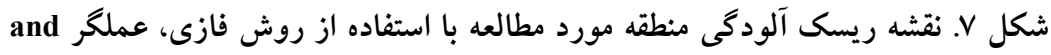

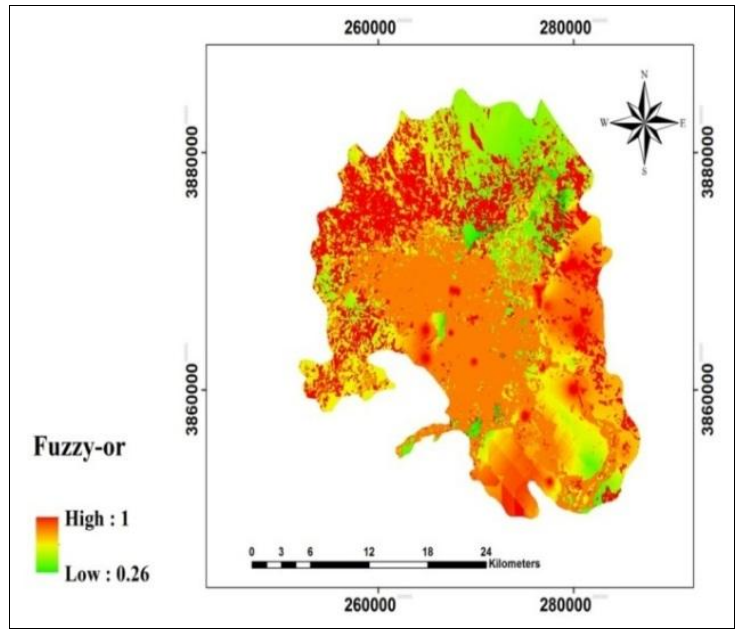

شكل ^. نقشه ريسك منطقه مورد مطالعه با استفاده از روش فازى، عملكر

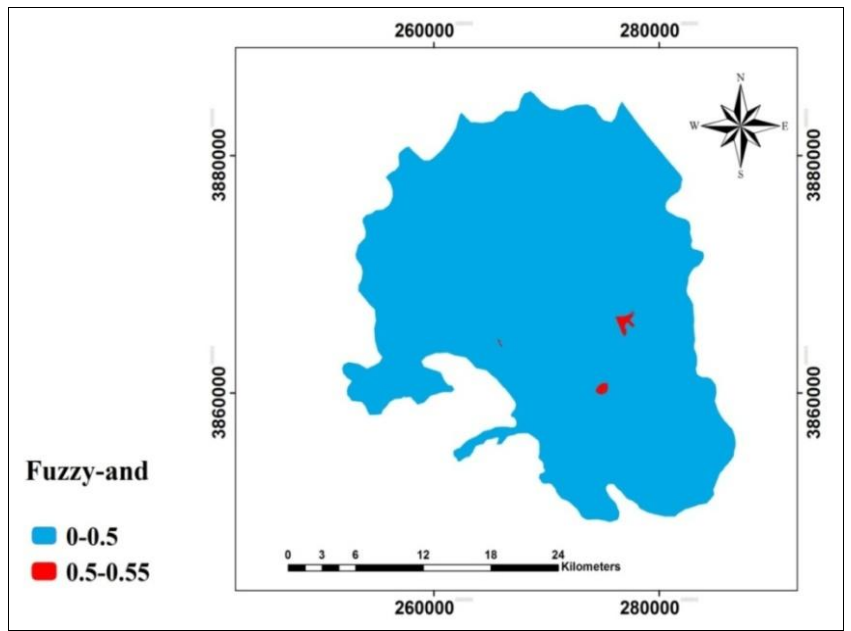

And شكل ه. نقشه طبقهبندى شده ارزيابى ريسك با استفاده از روش فازى عملكر 
نشريه علوم آب و خاك (علوم و فنون كشاورزى و منابع طبيعى) / سال بيست و دو / شماره دو / تابستان IrqV

جدول r. ارزيابى ريسك با استفاده از روش فازى (عملكر and)

\begin{tabular}{|c|c|c|c|}
\hline درصد مساحت & مساحت (هكتار) & دامنه ريسك & طبقه \\
\hline $99 / \mathrm{V}$ & Varro/ll & $0-0 / 0$ & 1 \\
\hline$\circ / \mu$ & TTE/AY & $\circ / \Delta-\circ / \Delta \Delta$ & r \\
\hline
\end{tabular}

كه مساحت آن بالغ بر وVVYNV هكتار است، در طبقه سـوم بـا

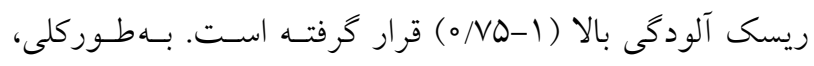

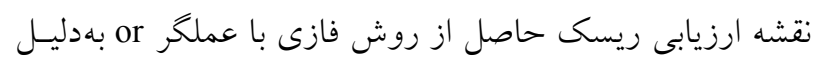

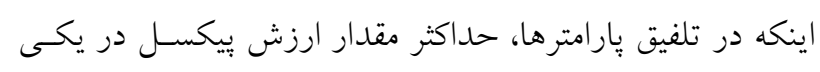

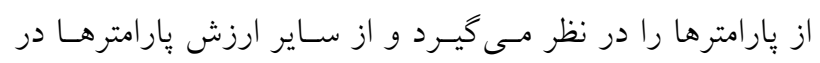
همان يِكسل صرف نظر مى كند، داراى حداكثر اعتماد و حداقل

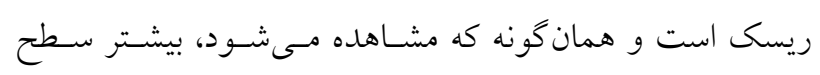

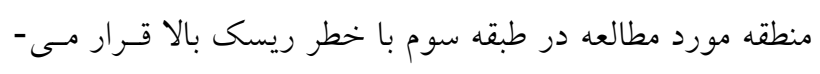

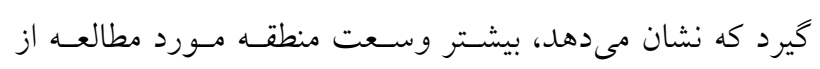

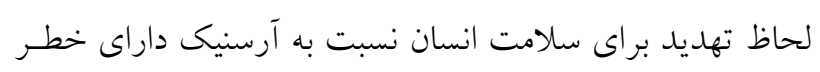
ريسك بالا است.

در روش فازى ابتدا متغير ورودى و خروجى مشخص شدا شهد

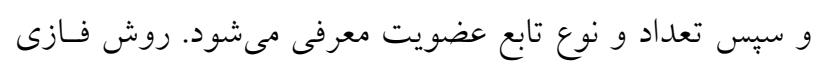

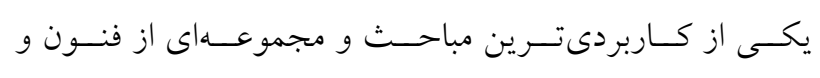

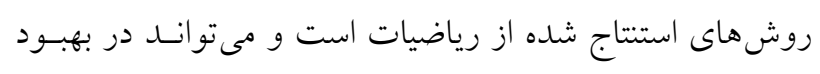

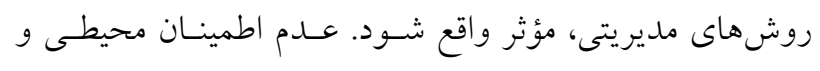

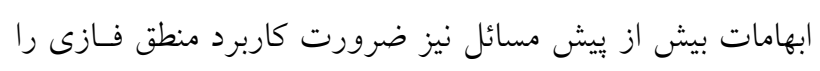

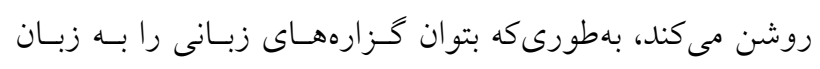
رياضيات ترجمه و اعمال كرد.

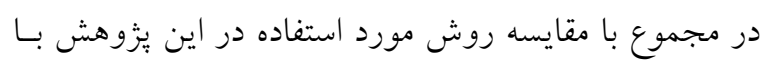

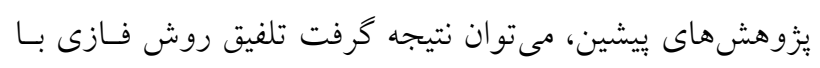

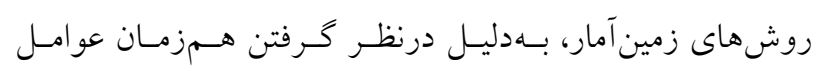

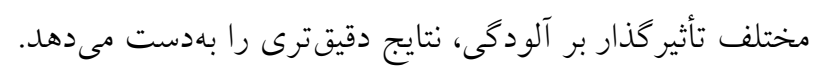

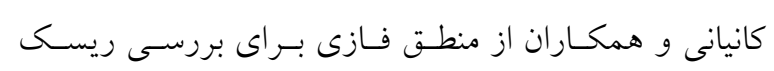

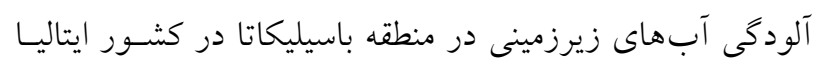

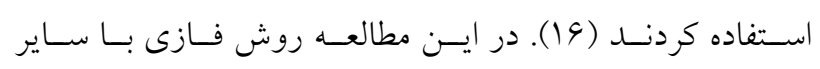

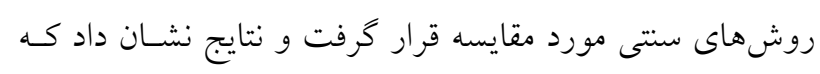

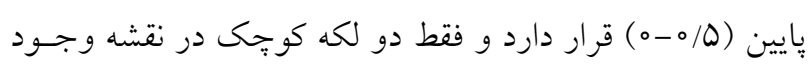

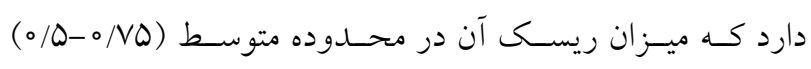

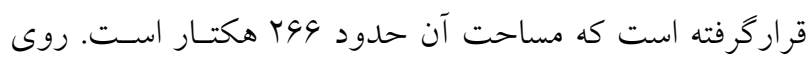

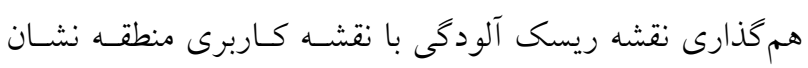

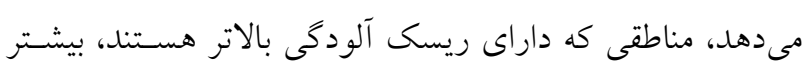

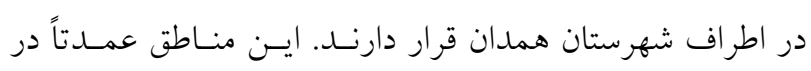

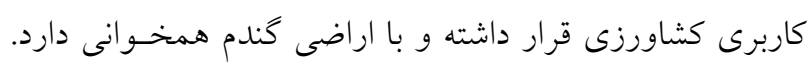

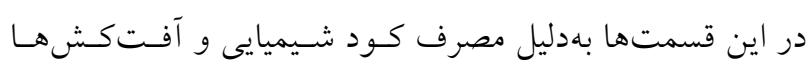

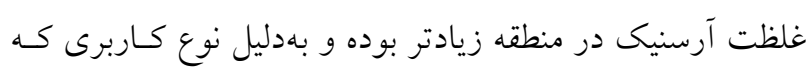

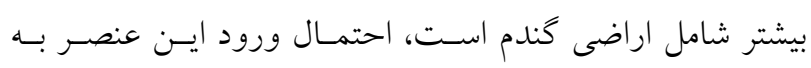
زنجيره غذايى بالا است.

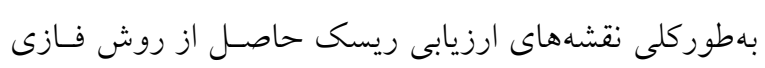

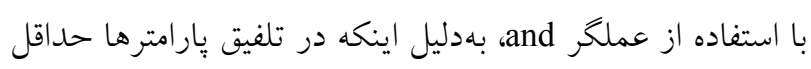

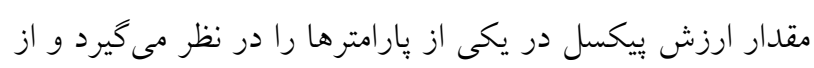

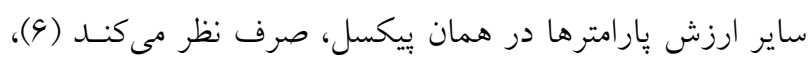

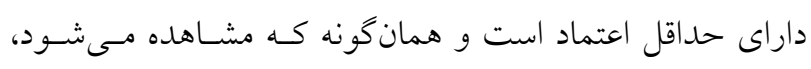

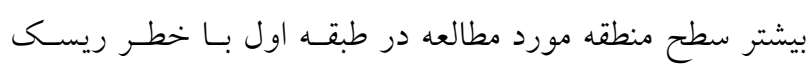

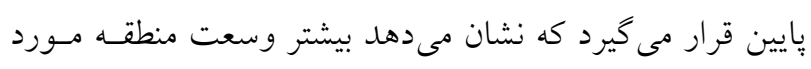

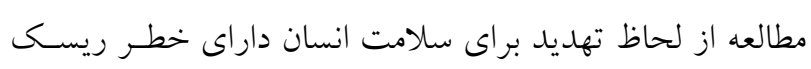
بايين است. ب) نقشه طبقهبندى شده ارزيابى ريسك با استفاده از روش فازى عملكر or در شكل ه ا نشان داده شده است.

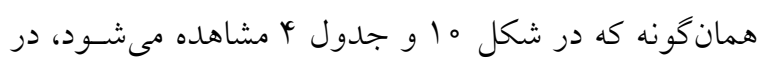

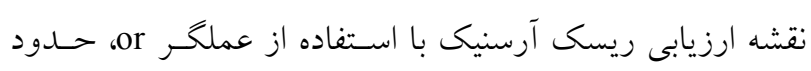

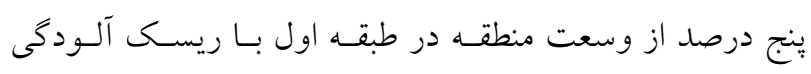

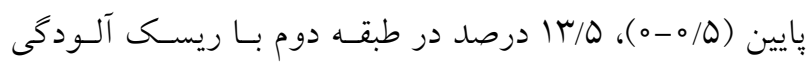

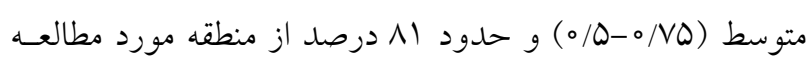




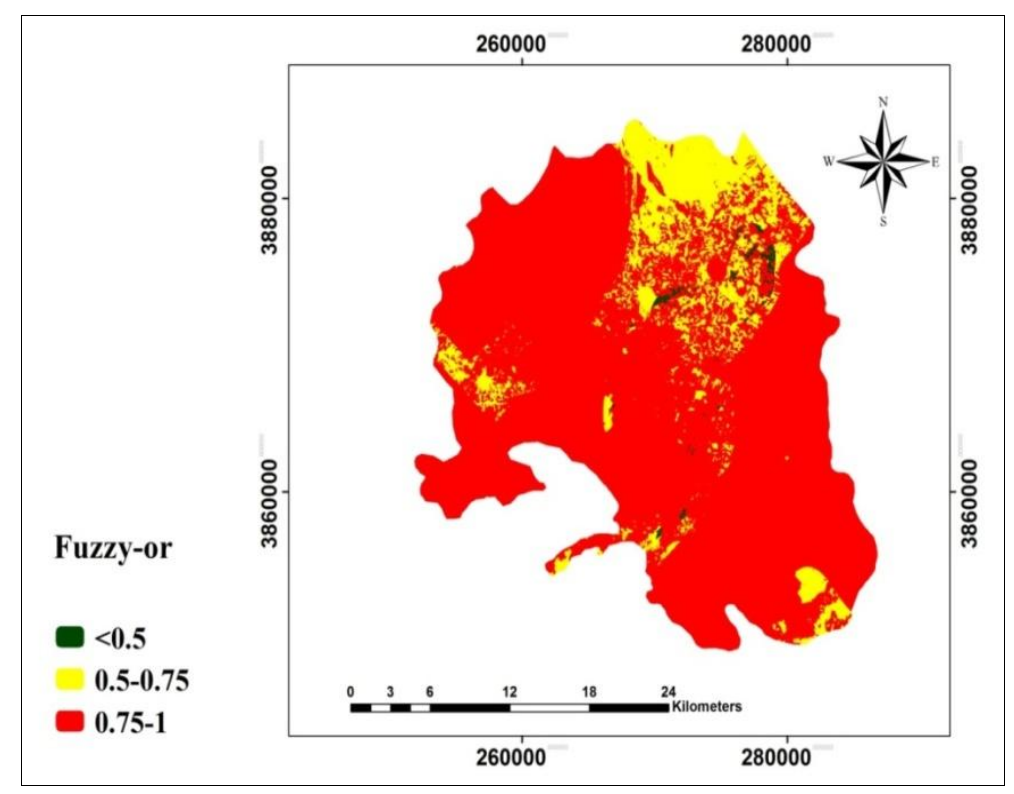

or شكل • ا. نقشه ارزيابى ريسك طبقهبندى شده آرسنيك با استفاده از روش فازى عملكر

جدول f. ارزيابى ريسك با استفاده از روش فازى (عملكر (or)

\begin{tabular}{|c|c|c|c|}
\hline درصد مساحت & مساحت (هكتار) & دامنه ريسك & طبقه \\
\hline.$/ 0$ & 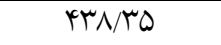 & $\circ-0 / 0$ & 1 \\
\hline $14 / 11$ & $\| r V_{0} / 94$ & $\circ / Q-\circ / N Q$ & r \\
\hline$\Lambda D / Y G$ & GWVYV/DG & $\circ / V Q-1$ & r \\
\hline
\end{tabular}

روش فازى ابزار مفيـدى بـراى بررسى ريسـى و برنامسهريـزى نتيجه گيرى بهمنظور بـهدست آوردن احتمـال ورود آرسـيكى بـهـ زنجيــهـ

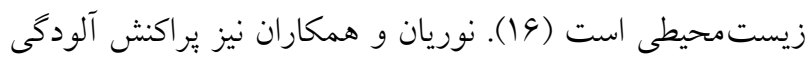

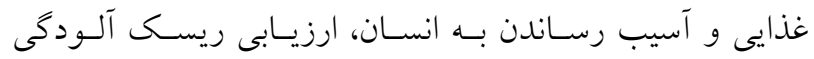
خاك به عناصر سنخين را در استان زنجان با استفاده از زمسين آمـار

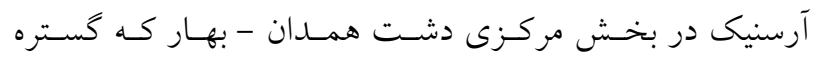
و خوشهبندى فازى، مورد مطالعه قرار دادند (Y) (T). تان و همكاران

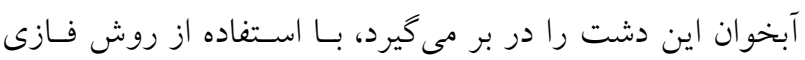

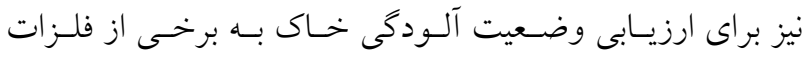

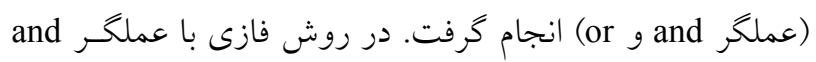

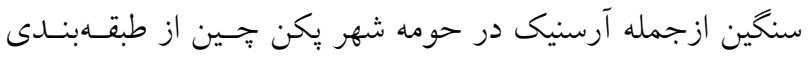

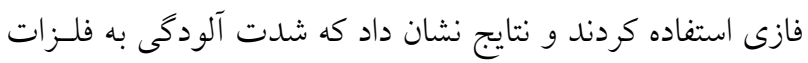

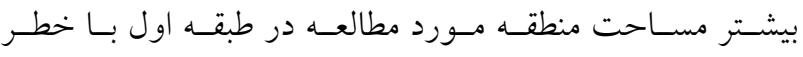

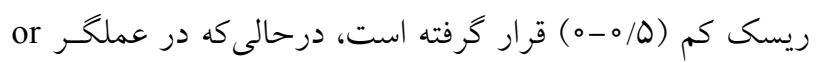

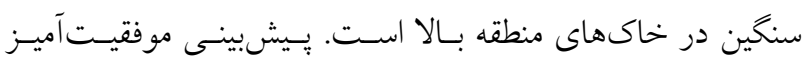
بيشتر وسعت منطقه مورد مطالعه در طبقه سوم با ريسكى زيـاد

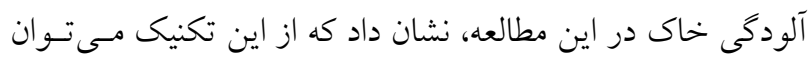

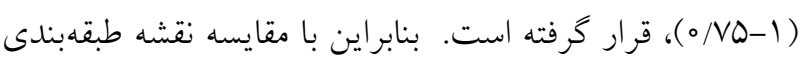

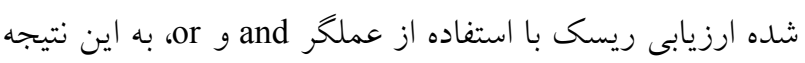

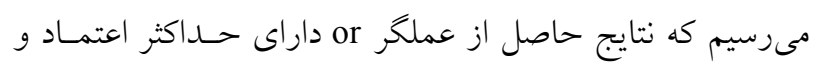
عملكر and داراى حداقل اعتماد است. قابل ذكر است، استيفاده

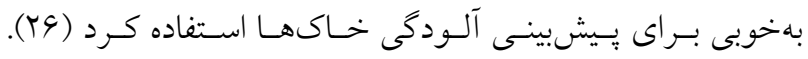

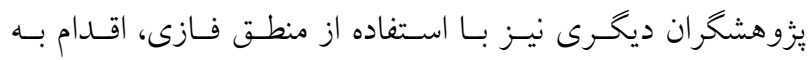

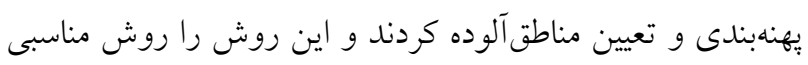
براى شناسايى مناطق آلوده و بحرانى دانستند (YQ). 
قابل ذكر است در اين مطالعـه، منـاطقى كـه داراى ريسـك آلودگى بالايى هستند، در اطــراف شـهر همــدان قــرار داشـته و

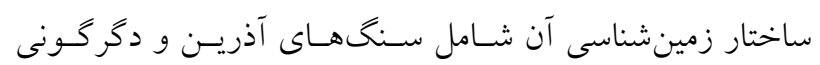
است كه داراى بيشترين غلظت زمينه آرسنيك است. عـلاوه بـر

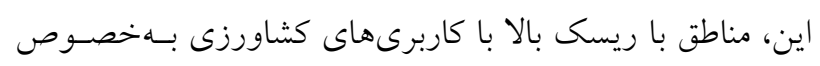
اراضى گندم، مطابقت داشت. در اين اراضى بهدليل مصرف زياد

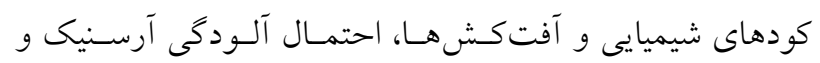
ورود اين فلز به زنجيره غذايى بالا اسـت.، بنـابراين آلـودگى در اين مناطق مىتواند متأثر از زمينشناسى منطقه و همجينين نتيجه فعاليتهاى انسانى باشد. از اينرو، بهنظر مىرسد منطقه نيازمند

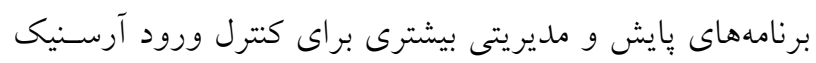

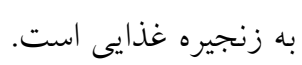

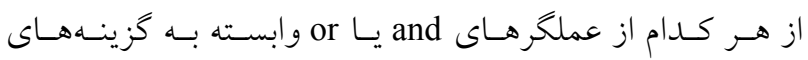
مديريتى است كه در منطقه مورد نظر اتخاذ مىشود. بايد توجـه

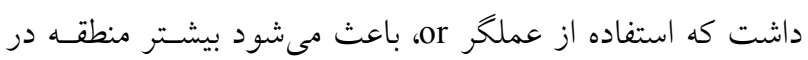
حالت بحرانى نمايش داده شود. با توجه بـهـ شـرايط موجـود در منطقه (محدوده غلظت عناصر، pH خنثى، كاربرىهاى موجـود)

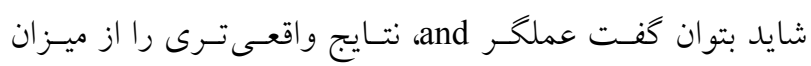
ريسك آلودگى آرسنيك منطقه نشان دهد. ييشنهاد مى شود در منـاطقى كـهـ مقـدار غلظـت آرسـنيك در خاى و آب زيرزمينى بالا و همجِنين مقدار بار امترهاى فيزيكى و

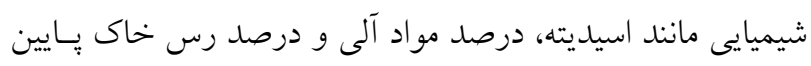
است و كاربرى كثـاورزى منطقــه داراى محصـولاتى بـا قابليـت

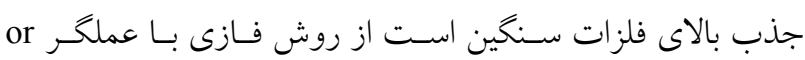
استفاده شود كه داراى حداكثر اعتماد و حداقل ريسك است.

\section{منابع مورد استفاده}

1. استاندارد كيفيت منابع خاى و رلهنماهاى آن. الو آوا. سازمان محيط زيست ايران.

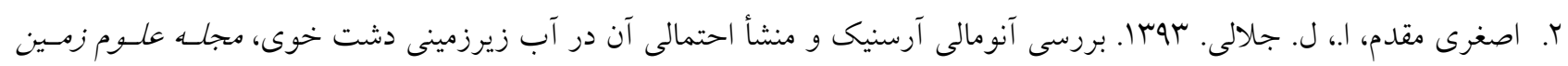
$.1 Y V-104:(94) Y 4$

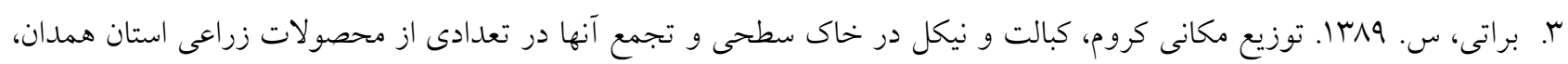

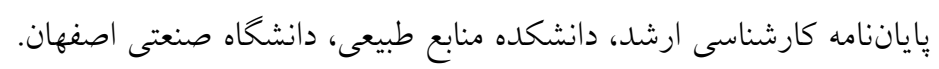

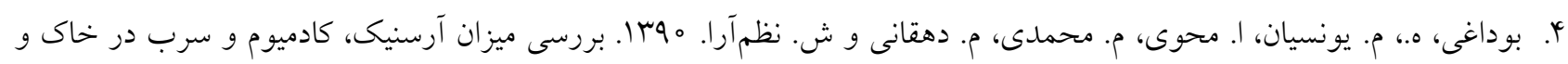

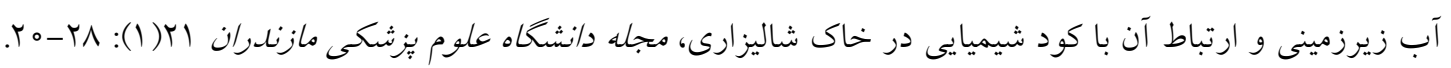

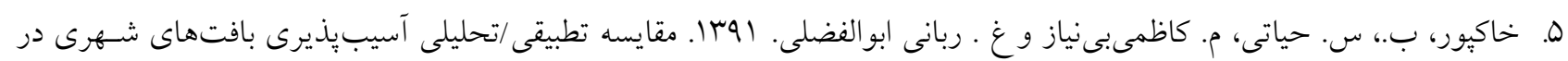

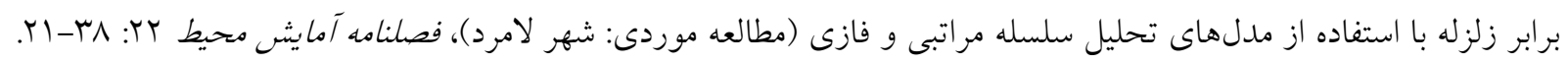

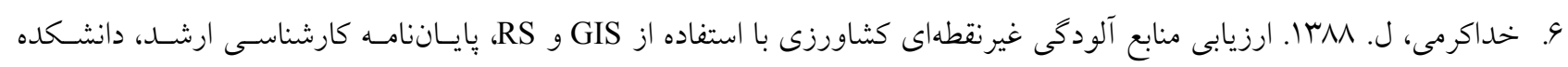

$$
\text { منابع طبيعى، دانشگاه صنعتى اصفهان. }
$$

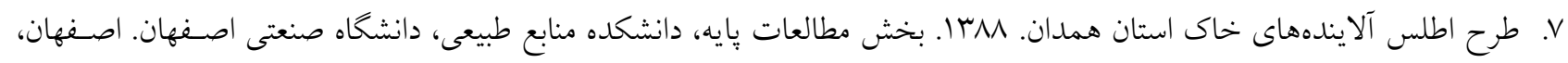
ايران.

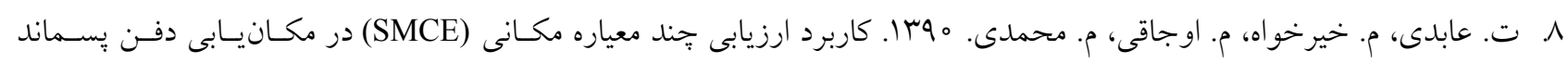

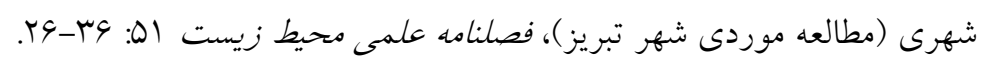

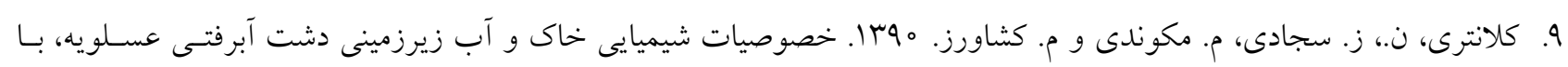

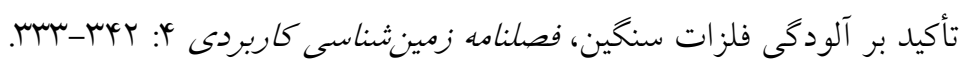




$$
\begin{aligned}
& \text { ه ا.نبى اللهى، ك.، ا. حيدرى، ن. تومانيان و غ. ثوابقى. rوسا. ارتباط خصوصيات خاك در سطوح مختلـف زئومورفيـك بـا تغييـرات }
\end{aligned}
$$

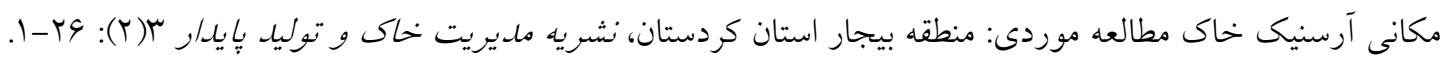

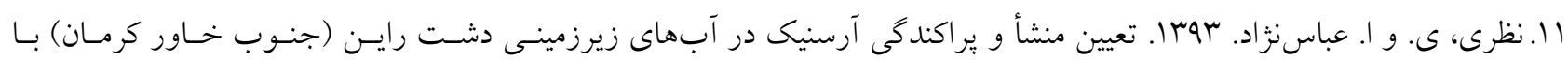

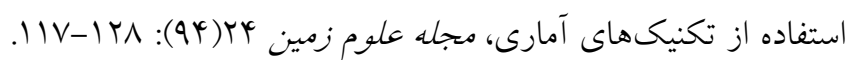

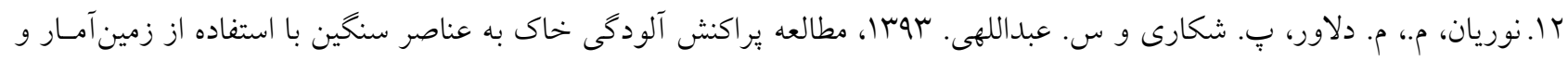

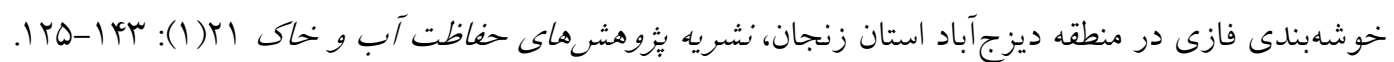

13. Akter, A. and M. H. Ali. 2011. Arsenic contamination in groundwater and its proposed remedial Measures, International Journal of Environmental Science and Technology 8: 433-443.

14. Appelo, T. 2006. Arsenic in Groundwater -World Problem, Seminar Utrecht 2006, Netherlands National Committee of the IAH.

15. Bissen, M. and F. H. Frimmel. 2003. Arsenic- a review, part I: Occurrence, toxicity, speciation, mobality, Journal of Acta Hydrochimica et Hydrobiologica 31(1): 9-18.

16. Caniani, D., D. S. Lioi, I. M. Mancini and S. Masi. 2015. Hierarchical classification of groundwater pollution risk of contaminated sites using fuzzy logic: A case study in the basilicata region (Italy), Water 7: 2013-2036.

17. Francisca, F. M. and M. E. Carro. 2009. Assessment of natural in groundwater in Cordoba Province, Argentina, Environ Geochem Health 31: 673-682.

18. Garcia, M. G., O. Sracek, D. S. Fernandez and M. Hidalgo. 2007, Factors affecting arsenic concentration in groundwaters from Northwestern Chaco-Pampean Plain, Argentina, Environmental Geology 52: 1261-1275.

19. Hakan, A. and N. A. Turan. 2015. Estimation of spatial distribution of heavy metals in groundwater using interpolation methods and multivariate statistical techniques; its suitability for drinking and irrigation, Environmental Monitoring and Assessment 187: 1-13.

20. http://www.hmrw.ir/SC.php?type=static\&id=54

21. Liu, X., W. Zhang, Y. Hu, E. Hu, L. Wang and H. Cheng. 2014. Arsenic pollution of agricultural soils by concentrated animal feeding operation (CAFAOs), Chemosphere 119: 273-281.

22. Mico C., L. Recatala, M. Peris and J. Sanchez. 2006. Assessing heavy metal sources in agricultural soils of an European Mediterranean area by multivariate analysis. Chemosphere 65: 863-872.

23. Ross, S. M. 1994. Retention, transformation and mobility of toxic metals in soils, Journal of Toxic Metals in SoilPlant Systems 63-152.

24. Sparks G. L. 2003. Environmental Soil Chemistry. Academic Press, San Diego, California, USA.

25. Sun, X. L., Y.G. Zhao, , Wang, H.L., Yang, L., Qin, C.Z., Zhu, A.X., Zhang, G.L., Pei, T., and Li, B.L. 2012. Sensitivity of digital soil maps based on FCM to the fuzzy exponent and the number of clusters. Geoderma. 171: 24-34.

26. Tan, M. Z., F. M. Xu, J. Chen, X. L. Zhang and J. Z. Chen. 2006. Spatial prediction of heavy metal pollution for soils in peri-urban Beijing, China based on fuzzy set theory. Pedosphere 16: 545-554.

27. Toxicological Profile for Arsenic, U.S. 2007. Department of Health and Human Services .Public Health Service, Agency for Toxic Substances and Disease Registry.

28. Ungaro, F., F. Ragazzi, R. Cappellin and P. Giandon. 2008. Arsenic concentration in the soils of the Brenta Plain (Northern Italy): Mapping the probability of exceeding contamination thresholds, Journal of Geochemical Exploration 96: $117-131$.

29. Weaver, R. W., J. S. Angle and P. S. Bottomley. 1994. Methods of Soil Analysts, Microbiological and Biochemical Properties, Part II, Soil Science of America INC, Wisconsia.

30. Guidelines for Drinking-Water Quality. 1998. World Health Organization (WHO), $2^{\text {nd }}$. Geneva. 


\title{
Arsenic Contamination Risk Assessment in Hamedan Plain-Spring Using the Fuzzy Method
}

\author{
M. Touzandejani* ${ }^{*}$ A. Soffianian and N. Mirghaffari ${ }^{1}$
}

(Received: January 16-2016; Accepted: June 11-2017)

\begin{abstract}
Among the heavy metals, arsenic is known as a carcinogen material and its high concentrations in the ecosystem can be a major concern for public health and environment. The aim of this study was to evaluate the risk map of arsenic contamination and the possibility of its entering into the food chain using the fuzzy method in the central part of the Hamedan-Bahar plain. For this purpose, arsenic concentration in 94 points of groundwater and 49 points of surface soil was analyzed and evaluated in the study area. Soil physico-chemical parameters (clay, organic matter and $\mathrm{pH}$ ), soil and groundwater contamination probability map, and land use map were selected as the input of this method. In the fuzzy method, two operators (and \& or) were used. In order to standardize the parameters, the fuzzy linear function was used. Comparing the classified risk assessment using these operators showed that the results of the operator had the maximum trust. So in areas where concentrations of arsenic in soil and groundwater were high, the physico-chemical parameters such as $\mathrm{pH}$, organic matter and clay content of the soil were low and agriculture products had a high ability to absorb heavy metals and ensure its better to use for the operator.
\end{abstract}

Keywords: Arsenic, Fuzzy method, Hamedan-Bahar plain, Risk

1. Department of Environment, Faculty of Natural Resources, Isfahan University of Technology, Isfahan, Iran.

*: Corresponding Author, Email: m.touzandejani91@gmail.com 